\title{
Common identity framework of cultural knowledge and practices of Javanese Islam
}

\author{
Sulistiyono Susilo
}

Diponegoro University Semarang

e-mail: sulistiyonosusilo@gmail.com

DOI: 10.18326/ijims.v6i2.161-184

\section{Ibnu Syato}

State University of Islamic Studies of Walisongo, Semarang

e-mail: greatjunius88@gmail.com

\begin{abstract}
Previous literatures apparently argued that Javanese Islam is characterized by orthodox thought and practice which is still mixed with pre-Islamic traditions. By using approach of the sociology of religion, this article tries to explain contextualization of Islamic universal values in local space. The results showed that synthesis of orthodox thought and practice with pre-Islamic traditions is doubtless as a result of interaction between Islam and pre-Islamic traditions during the Islamization of Java. In addition, this study found the intersection of Islam and Javanese culture in the terms of genealogy of culture, Islamic mysticism, orientation of traditional Islamic teachings, and the conception of the power in Javanese kingdom. Since kejawen practices accordance with Islamic mysticism can be justified by the practice of the Muslims. Thus the typology of the relationship between Islam and Javanese culture are not contradictory but dialectical. Finally, a number of implications and suggestions are discussed.
\end{abstract}


Berbagai literatur sebelumnya mengenai studi Islam di Jawa umumnya berpendapat bahwa Islam Jawa ditandai dengan pemikiran dan praktek yang masih tercampur dengan tradisi pra-Islam. Dengan menggunakan pendekatan sosiologi agama, artikel ini mencoba untuk menjelaskan makna dari kontekstualisasi nilai-nilai universal Islam pada lingkup lokal. Hasil penelitian menunjukkan bahwa sintesis pemikiran dan praktek dengan tradisi pra-Islam merupakan hal yang lumrah sebagai hasil interaksi antara Islam dan tradisi praIslam selama periode Islamisasi. Penelitian ini menemukan persamaan identitas antara Islam dan budaya Jawa dalam hal genealogi budaya, mistisisme Islam, orientasi pengajaran Islam tradisional, dan konsepsi kekuasaan di keratonkeraton Jawa. Karena praktek kejawen dapat dijustifikasi sesuai dengan praktek mistisisme Islam, maka tipologi hubungan antara Islam dan budaya Jawa tidak bertentangan tetapi bersifat dialektis.

Keywords: Kejawen; Islamic mysticism; Scripturalism; Javanese culture

\section{Introduction}

Javanese culture has become the central study of many Indonesianists, due to its historical domination in the field of politics, commercial economy, culture, and its status as a major ethnic groups in the archipelago. Throughout its history, the Javanese culture gradually absorbed the various elements and influences and affected by a variety of interactions for more than a millennium from external cultures and civilizations, such as the native reverence for ancestral and natural spirits, dharmaic civilization from Hindu and Buddhist beliefs, and Islamic monotheistic belief, and in a limited scope is affected by Christian, Western philosophy and modern ideas.

Some orientalists claimed that the main characteristics of the synthesized element between Javanese culture and external ideas is syncretism. ${ }^{1}$

${ }^{1}$ See Clifford Geertz, Religion of Java, Chicago: The University of Chicago Press, 1960, 121; Andrew Beatty, "Adam and Eve and Vishnu: Syncretism in the Javanese slametan.", Journal of the Royal Anthropological Institute, (1996): 271; Lode Frank Brakel, 
Especially in the relation between Javanese culture and Islam as the largest religion adhered by Javanese people, the study of the Javanese culture characteristics is considered unique because Islam faith essentially against toward syncretism belief. The study becomes more interesting after an eminent American anthropologist, Clifford Geertz (1926-2006) conducted research that was eventually published as a book entitled The Religion of Java (1960). Geertz divided 1960s' Javanese community in three variants, namely santri (Islamic boarding students), abangan or kejawen (javanist) and priyayi (aristocratic class). The book that arguably is the foremost thought in the study of Javanese Islam, has a significant role in understanding the character and formulation of this culture. Since then, Javanese Islam widely studied by many scholars, whether approving or rejecting the Geertz's classification. Geertz viewed orthodoxy as the original Islamic feature, and resulted the actualization of Javanese Islam as a deviation of Islam.

However, Geertz widely criticized for bias in looking at the actualization of Islam by the Javanese community. Geertz's classification mixed the stratification of social groups with belief groups and biased in understanding actualization of Islamic teachings locally. ${ }^{2}$ As a discursive entity, Islam as a religious as well as the tradition is very important to understood through its actualization diversity within local context. In Islamic teaching, the local actualization of Islam also got a jurisprudential justification. The idea of contextualization of Islam associated with the conception of Islam 'șaih li kull zamān wa makān' (Islam of all times and places). Exploration of these rules can facilitate an understanding of the univer-

\footnotetext{
"Islam and local traditions: syncretic ideas and practices.", Indonesia and the Malay world, Volume 32, Number 92 (2004), 5.

${ }^{2}$ Nurcholis Madjid, "Islamic Roots of Modern Pluralism: Indonesian Experience.", Studia Islamika, Volume 1, Number 1 (1994), 60-62.
} 
salistic elements of Islam that is practiced and communicated in the form of local groups. It is important to identify the locality of Islamic teaching by analyzing the variety of contexts, such as social, textual, ritual, and cosmological dimension in a culture of Muslim society. ${ }^{3}$ Accordingly, selfidentification of Muslims should be regarded as an important object in the study of Islamic culture. ${ }^{4}$ Hence, the study of Islamic teaching application by Javanese community in sociological and cultural sphere, need to identify the relational fact between Javanese culture and Islam. The rationale on the study of Islamic culture in the local context of Java, as well as Islamic teachings application in other hemispheres, is how to describe and analyze the universal principles of Islam that were realized in the various social and historical context without undermining Islam as an 'essence' in one side and as a 'tradition' on the other. ${ }^{5}$

By using the approach of the sociology of religion, this study attempts to identify the aspects of the relational identity formation of Javanese Muslim community as a form of local wisdom variation that is sometimes mistakenly understood as syncretic by combining aspects of different religions. By taking the starting point of the theory of Geertz's magnum opus, The Religion of Java (1960), this study attempts to analyze some cultural bias to the theory, by using research library approach through the identification of antithesis of Geertz's theory of the Indonesianists like Robert Hefner, Merle Ricklefs, Niels Mulders, Mark Woodward, Martin van Bruinessen and M.B Hooker which are relevant to the formulation of Islamic identity of Javanese community.

\footnotetext{
${ }^{3}$ Dale Eickelman, "The study of Islam in local contexts." , Contributions to Asian Studies, Volume 17 (1982), 76.

${ }^{4}$ Ronald Lukens-Bull, "Between Text and Practice: Considerations in the Anthropological Study of Islam”, Defining Islam: A Reader, Volume 59 (2007), 60.

${ }^{5}$ Dale Eickelman, "The study of Islam in local contexts..., 76.
} 


\section{Sociology of Religion in Javanese culture}

Sociology of religion primarily analyses 'the influence of society, culture and personality on the origin, doctrines, practices and kinds of religious groups as well as the ways that religion affects society, culture and personality', ${ }^{6}$ The study of sociology of religion requires a theoretical basis on sociology, society, and religion. Religion in sociological perspective is the discipline of sociology analyzing the main text of a religion and presenting as well as illustrating the major theories of sociology in order to understand the social dimension of religion. ${ }^{7}$ Since religion plays many vital roles throughout human generations, sociology of religion viewed religion of the three functions : functionalist, conflict and interactionalist. ${ }^{8}$

If we analyze religions from the dimensions of tradition, contextualization of religious traditions can occur between the main text and literature of a religion in one side with universal expression and local interpretation on the other. Localities will produce elements of derivatives that are provincial, inferior or imperfect realization as well as 'popular' and 'vulgar' culture of its parent culture which religiously assumed as 'genuine', 'noble' universal, and superior.' The basic conceptual problem of sociological studies of Islam is how to apply an ethnographic study on the practice of religion in the sphere of local and small-scale variation to the larger entities such as Islamic belief and civilization. In the study of such kind, the work of Geertz became a central issue.

The study of Islam in the Javanese community has consistently just focus with Islamic orthodoxy and differences of socio-economic context,

${ }^{6} \mathrm{~J}$ Milton Yinger, Religion, Society and the Individual: an Introduction to the Sociology of Religion, Oxford: England: Macmillan, 1957, 1.

${ }^{7}$ Keith A Roberts and David Yamane, Religion in Sociological Perspective, Sage Publications, 2014, 2-8.

8 Amber Heady and Lynn Ruffner, "Religion and sociological perspective", Religion Volume 8 (2010), 31.

${ }^{9}$ Dale Eickelman, "The study of Islam in local contexts..., 76. 
political behavior, and social conflict. ${ }^{10}$ For example, Clifford Geertz classified three variations of Javanese Islam which are correlated each other in the context of a particular social class. Geertz's label on the unique tradition of syncretic amalgalm between animism belief and practice, Hinduism-Buddhism and Islam, particularly Sufi thus forming beliefs and values of native Javanese. Geertz's terminology of abangan in the context of Javanese culture become the most controversial label. Abangan tradition as the dominant element in the Javanese community defined as a syncretic mix of animism, Hinduism and Buddhism and Islam. The tradition of santri (Islamic students) identified as orthodox tendencies toward Islamic teaching, which are usually embraced by merchants and rich farmers. Lastly, the priyayi (aristocrat), was identified as the nobility of the elite that controls the bureaucratic power of Javanese people who are affected by the values of Hinduism and Buddhism teaching. ${ }^{11}$

Many Indonesianists stated that Geertz's typology actually has a lot of shortcomings. ${ }^{12}$ Geertz was bias in taking only the views of the modernists as Muslim representation. Basically, this bias view was conducted with the significance of the role of Islam in the historical dimension of the religious community of Javanese people that began with the victory of Islam in politics that characterizes the Indonesia political realm in the early 20th century, and its large role in the political, social, cultural and religious setting. ${ }^{13}$ In the 1930 s, there were a renewal movement to modernize Islam by the reformer, which became a new challenge for Javanese

\footnotetext{
${ }^{10}$ Robert W Hefner, "Islamizing Java? Religion and Politics in Rural East Java”, The Journal of Asian Studies, Volume 46, Number 03 (1987), 533.

${ }^{11}$ see more detail in Clifford Geertz, Religion of Java..., 127.

${ }^{12}$ Hodgson, in the Venture of Islam, as quoted by Robert W Hefner, "Islam, State, and Civil Society: ICMI and the Struggle for the Indonesian Middle Class", Indonesia, Volume 56 (1993), 1.

${ }^{13}$ See Merle Calvin Ricklefs, Islamisation and Its Opponents in Java, Singapore: NUS Press, 2012, 1.
} 
people and Islamic traditional groups. ${ }^{14}$ Geertz's view of modernists Muslim representation, resulted the aboriginal forms for local actualization of Islam. ${ }^{15}$

Acculturation of Javanese culture with several external religions and traditions which come to Java, including the acceptance of external ideas, are the implications of the world view (weltanschauung) of the Javanese community. The tradition of Islam and Javanese cultural amalgalm started from the Javanese society worldview as their comprehensive conception to the world. Hence, it is necessary to take the opinion of Mulders:

The Javanese weltanschauung (Javanism) is based on the conviction of the essential unity of all existence. This worldview is encompassing more than religion: it views human existence within a cosmological context, making life itself a religious experience. In this view of life it is not possible to separate the religious from non-religious elements; Human existence is inescapably related to supernature and it is senseless to sharply extinguishing between the here and now and the beyond and timeless. ${ }^{16}$

The Javanese assume that overall of existence governed by nature and has become a moral duty to live harmoniously with the motion and the rule of nature. They should be encouraged to seek self-harmony, that govern people regarding their self-conduct, social relations, rules of customs and social solidarity. ${ }^{17}$ Moral rules emphasis on stability, tranquility, harmony, politeness, fineness, patience, acceptance, and self-restraint toward lust. Individual life is subordinated by community, and then society is subordinated by nature to achieve harmony

${ }^{14}$ Martin van Bruinessen, "Global and local in Indonesian Islam”, Southeast Asian Studies, Volume 37, Number 2 (2007), 56.

${ }^{15}$ Nurcholis Madjid, "Islamic Roots of Modern Pluralism..., 60.

${ }^{16}$ JA Niels Mulder, "Aliran Kebatinan as an Expression of the Javanese Worldview”, Journal of Southeast Asian Studies, Volume 1, Number 2 (1970), 105.

${ }^{17}$ JA Niels Mulder, "Aliran Kebatinan as an Expression of the Javanese Worldview..., 105. 
and unity with God (manunggaling kawula gusti). ${ }^{18}$ The Javanese seeks asceticism to avoid the worldly wealth and comfort, as well as avoid conflict, competition and disputes. Whoever can live courteously with themselves and the community, then $\mathrm{s} / \mathrm{he}$ is considered to have lived harmoniously with God as a Single Existence. ${ }^{19}$ As a result, it is only little space available for adventure and self-exploration. ${ }^{20}$

Harmonization (Javanese: kerukunan) is has a central role in the life of Javanese people, and contextualizes the Javanese community and perceives their life, motivations and social relationships. Traditional Javanese society fulfill their culture with social solidarity in doing all the activities of life. ${ }^{21}$ The cultural value of harmony and mutual assistance or helpfulness for Javanese is interpreted as social solidarity and economic egalitarianism, such as the harvest together, and distribution of crop results.

The external beliefs and ideologies that came to Javanese people would be adapted to the essence of the supernatural being of Javanese. ${ }^{22}$ Even though Javanese culture is characterized as tolerant and open to new ideology and religion, historical evidences, as will be presented in the next section, suggested that all of external entities were adapted in line

${ }^{18} \mathrm{JA}$ Niels Mulder, "Abangan Javanese religious thought and practice", Bijdragen tot de Taal, Land-en Volkenkunde 2/3de Afl (1983), 261.

${ }^{19}$ JA Niels Mulder, "Aliran Kebatinan as an Expression of the Javanese Worldview..., 105; JA Niels Mulder, "Abangan Javanese Religious Thought and Practice..., 260.

20 There are exceptions from this generalization where the culture of northern coast (pesisiran) of Java Island (such as Jepara, Demak, Kudus, Tuban, Gresik and Ampel in Surabaya) showed a tendency to live openly to the external ideas, egalitarian, and more orthodox in practising Islam. These towns are the earliest place to get the teaching of Islam in Java Island. In this region, orthodox students (santri) are among the largest population. Commitment to Islam is regarded as religious norm. See M B Hooker, "Muhammadan Law and Islamic Law," In Hooker, ed., Islam in South-East Asia..., 59.

${ }^{21}$ JA Niels Mulder, "Abangan Javanese Religious Thought and Practice..., 260-267.; Mary Hawkins, "Is Rukun dead? Ethnographic Interpretations of Social Change and Javanese culture", The Australian journal of anthropology, Volume 7, Number 1 (1996), 218.

22 JA Niels Mulder, "Aliran Kebatinan as an Expression of the Javanese Worldview”, Journal of Southeast Asian Studies, Volume 1, Number 2 (1970), 105-114. 
with character and personality of the Javanese. ${ }^{23}$ World religions that are applied in the local context would have implications for the elaboration, understanding, and reproduction of any ideology and practice by adjusting of their own place and momentum. ${ }^{24}$ By taking the theory of Ann Swiddler, stating that cultural and ideological elements encourage communities to construct various types of action, by providing the noble values as the orientation of the action, and establishing a repertoire or tool kit of customs, habits and styles in which the public construct their action strategies. ${ }^{25}$ The acceptance by filtration of Javanese community toward external religion and ideology can be regarded as an establishment to minimize religious conflict and strengthen social identification that is reflected in the Javanese world view. ${ }^{26}$

\section{Islamic scripturalism versus Javanese spiritualism}

Islamization of the Java is a continuous cultural transition, complex and full of surprises along more than 600 years of its presence in the archipelago. ${ }^{27}$ Historical collective identity of Javanese Muslim is basically formed through the synthesis of the influence of Hinduism and Buddhism tenets since the early AD until the 14th century, Islamic expan-

\footnotetext{
${ }^{23}$ see for more detail discussion in Michael RJ Vatikiotis, Political Change in Southeast Asia: Trimming the Banyan Tree, Volume 10, Taylor \& Francis, 1996; Andrew Beatty, "Adam and Eve and Vishnu: Syncretism in the Javanese Slametan", Journal of the Royal Anthropological Institute (1996): 271-288; Nurcholis Madjid, "Islamic Roots of Modern Pluralism..., 60 62.

${ }^{24}$ Dale Eickelman, "The study of Islam in local contexts..., 75.

${ }^{25}$ Ann Swidler, "Culture in action: Symbols and strategies.", American sociological review (1986): 273. See also for discussion about how religious concepts are used to motivate and direct actions in J L Barrett, "Exploring the natural foundations of religion", Trends in Cognitive Sciences, Volume 4, Number 1 (2000): 29-34.; and, Clifford Geertz, "Religion as a Cultural System", in Interpretation of Cultures: Selected Essays, Fontana Press, 1993, 89.

26 Blake E Ashforth and Fred Mael, "Social identity theory and the organization," Academy of Management Review, Volume 14, Number 1 (1989), 20.

${ }^{27}$ Merle Calvin Ricklefs, Mystic Synthesis in Java: a History of Islamization from the Fourteenth to the Early Nineteenth Centuries, EastBridge, 2006, 320.
} 
sion of the 14th century to the present, and the penetration of Western culture since the time of colonialism (16th to 20th century). Islamization of Java that began in the 14th century characterised with tension and conflict between the Islamic beliefs and Javanese culture. In subsequent periods, the Javanese community attached themselves as having a fundamental identity of 'muslim'. In the late 19th century to the early 20th, the process of Islamization was in crucial period along with the strengthening of colonialism and the arrival of puritanical Islam. Islam as a religious as well as imported traditions has contradictory elements with Javanese values that tend to idolize individuals. ${ }^{28}$ The modernists who considered the personality cult as a feudal culture, encouraged people to follow the "pure and original Islam", by eliminating the indigenous syncretism of Islamic elements.

Many previous studies regarding Javanese Islam can be divided into three variants in receiving the relationship of Islamic doctrinal aspects and local mysticism. The first view regarded local mysticism as not part of pure Islamic teachings, but still expressed abangan as a Muslim in a broad sense. ${ }^{29}$ In the theory of culture, this view stated that abangan, the nominal or non-practising Muslims, is a group that affected to and subordinated by the teachings of Islam, with the understanding that they put more emphasis on the mystical aspects rather than on the legal and ritualistic dimension of Islam. Abangan is regarded as a relevant alternative religious path that grounded in Javanese society, because they did not

\footnotetext{
${ }^{28}$ Clifford Geertz, The interpretation of Cultures: Selected Essays, Volume 5019, Basic books, 1973; Jerry D Moore, Visions of Culture: an Introduction to Anthropological Theories and Theorists, Rowman Altamira, 2000.

${ }^{29}$ The term of abangan had appeared in various Javanese literatures and Western references since the mid-nineteenth century. See, Merle Calvin Ricklefs, "The birth of the abangan," Bijdragen tot de taal-, land-en volkenkunde/Journal of the Humanities and Social Sciences of Southeast Asia, Volume 162, Number 1, (2006), 36.
} 
have enough information about teaching of the true Islam. ${ }^{30}$ Since the beginning of Islamization, the Javanese already had a different degrees of accommodation of looking at local practices and Islamic beliefs. ${ }^{31}$ This difference led to fragmentation in the actualization of Islam due to the penetration of Javanese culture. ${ }^{32}$

In the context of religious hegemony, kejawen community or called abangan, is a terminology for local-style appreciation of Islamic teachings and practises by Javanese community. Abangan is a Javanese term to refer to groups or individuals that are not fully in implementing Islamic law. Use of antagonistic term between abangan and santri showed two opposite poles and gaps in meaning of the teachings of Islam. Although it is one of the constituent elements of collective identity of Javanese Mus$\mathrm{lim}$, the increasing growth of strength and domination of Islamic orthodox community in Java did not decrease the Kejawen community strength. The epistemic reasoning of Javanese Muslims differs from the mainstream Muslims that classify them as the others in the view of Islam. The abangan category, however, is defined by failure in the eyes of the more pious, and used to insult 'people to behave as improper Muslims'. ${ }^{33}$

However, other studies as can be classified as second opinion, still refuse the coherence or linkage the local value and the original Islam. This 2.

${ }^{30}$ Harun Nasution et al., (ed.), Ensiklopedia Islam Indonesia, Jakarta: Djambatan, 1992,

${ }^{31}$ John L Esposito, Oxford History of Islam, New York: Oxford University Press, 1999, 429; M B Hooker, "Muhammadan Law and Islamic Law," In Hooker (ed.) Islam in SouthEast Asia..., 59; Robert W Hefner, "Islam, State, and Civil Society: ICMI and the Struggle for the Indonesian Middle Class.”, Indonesia, Volume 56 (1993), 1.

${ }^{32}$ Harun Nasution et al., (ed.), Ensiklopedia Islam Indonesia..., 2.

${ }^{33}$ Merle Calvin Ricklefs, "The birth of the abangan..., 35. Since kejawen considered as deviation of Islamic teaching, many people avoid to ascribe themselves as kejawen. In addition, the label of abangan by Geertz, excluding the Western-educated middle class, is a form of derogatory, see Robert W Hefner, "Islam, state, and civil society..., 1.; Robert W. Hefner, "Islamizing Java? Religion and Politics in Rural East Java", The Journal of Asian Studies, Volume 46, Number 03 (1987), 533. 
opinion clearly stated that local mysticism could not be considered as an actualization of Islam and expressed that abangan typology as a deviation of Islam. One of them is William Roff who rejected the essentialist view of Islam and defined Muslims narrowly as a person who receives the sharia, and prioritize aspects of sharia. He stressed that the essentialist view, i.e accepting Islam only from mystical-spiritual aspect, and not a formal dimensions, can easily justify anyone as Muslim even though s/he did not fully follow sharia. ${ }^{34}$ For instance, many stories in Persia and Java about saints of sufi, who commonly states that sharia is an outer dimension that is addressed for the laity who need assistance to know right and wrong of Islamic tenets but can not lead to a deep mystical dimension. This second paradigm thereby departed from the views which assume sharia, or original Islam, just from the aspect of the theological doctrines and legal system alone. On the other hand, this opinion regarded mystical and Sufism dimension as non-doctrinal, even considered heretical, because it can easily blend the concept of local mysticism and accommodate the outside aspects of Islamic teachings. This opinion focused on the more orthodox lifestyle of sharia, scriptural aspect of Islam, and refused to compromise on local traditions. ${ }^{35}$ Scripturalism, in the Geertz's category, defined as interpretation of orthodoxy to keep the details of religious traditions, ruling by specific deeds, and rejecting inconsistent practices with the doctrine.

The third opinion stated that local mysticism can be considered as the full actualization of local Islam, and expressed that there is no syncretism between Javanese tradition, Hinduism-Buddhism and Islam. This view is classified as antithetical theory to Javanese-Islam syncretism of Geertz.

\footnotetext{
${ }^{34}$ Ronald Lukens-Bull, "Between Text and Practice: Considerations in the Anthropological Study of Islam.”, Defining Islam: A Reader Volume 59..., 60.

${ }^{35}$ Clifford Geertz, Religion of Java..., 160.
} 
This opinion stated by many Indonesianists. A study by Woodward examined the penetration of Islam and the pattern of Javanese culture in the sultanate of Yogyakarta. ${ }^{36}$ This study analyzed the concept of the implementation of sharia and sufism, and revealed that syncretism did not occur in the process of Islamisation in Java. Implementation of Islam in Java were not mixed up with the concept of Hinduism, Buddhism and animism as understood by the former orientalists. Islam in Java was acculturated with local culture in order to make Islam as new entity more acceptable to the local community and context. Woodward showed evidence that Islamic law and its rituals in Yogyakarta, which is regarded as the cultural center of Javanese realm, carried out similarly as the original teaching of Islam. Therefore, Woodward rejected the theory of syncretism of Javanese Islam. Similarly Ricklefs stated Geertz's made systematic error in placing santri/students as the antithesis of abangan. According to him, the terminology of santri which mean the boarding school pupils could not accommodate all Javanese Muslims that identified themselves as non-abangan. ${ }^{37}$

There is a strong tendency for scholars to provide an alternative understanding of Geertz's theory in order to minimize the significance of outlook of Islamic scripturalist in the religious life in Southeast Asia. The local variation of Islam, especially in Java, has been mistakenly viewed as synthesis of animism. For instance, slametan seen as representation of animists-syncretic culture to build the unity of the mystical and social solidarity of the abangan. ${ }^{38}$ Woodward argued that slametan is an Islamic rite

\footnotetext{
${ }^{36}$ Mark R. Woodward, Islam in Java: Normative Piety and Mysticism in the Sultanate of Yogyakarta, Association for Asian Studies Monograph XLV, Tucson: The University of Arizona Press, 1989.

${ }^{37}$ Merle Calvin Ricklefs, Mystic Synthesis in Java: a History of Islamization from the Fourteenth to the Early Nineteenth Centuries, EastBridge, 2006.

${ }^{38}$ Clifford Geertz, Religion of Java..., 11.
} 
of Javanese that includes Islamic piety wrapped in local nuance. ${ }^{39}$ Based on these views, there are at least some criticism toward Geetz's typology of Javanese Islam. The first is his tendency to define religiousity as the behavior of individuals and social which consistent with scriptural aspect of Islam. Secondly, there is a view to negate cultural pattern as a form of religious actualization in a society. In the case of social tendency against orthodoxy and scriptural aspect of religion, there was a mistake to assume that wherever Islam can actualised uniformly. Even in the Islamic tenets, over time changes is actually expected..$^{40}$

\section{Common identity framework of Islam and Javanese culture}

This section discusses the relational aspects between Islam and Javanese culture. As discussed previously that the process of Islamization in Java forms two opposite poles, namely muslim scripturalism and Javanese spiritualism. The formal dimension of Islam emphasizes on rituals consistent with the doctrine, while Javanese worldview focuses on essential unity of all existence to God without having to go through the process of legalistic practices. Accordingly, Kejawen which tends to ignore the formalistic and liturgical teachings of Islam would be considered as deviant. On the other hand, the Javanese people who still practices Islam are deemed to color the syncretic to the teachings of Islam.

However, in several aspects, santri who represent 'pure Islam' can meet on the mystical-supernatural aspects with abangan as a representation of Javanese culture. For instance, slametan and mystical practices of abangan still practiced largely by the santri. The relationship between Islam and

\footnotetext{
${ }^{39}$ Mark R. Woodward. "The "Slametan": Textual Knowledge and Ritual Performance in Central Javanese Islam", History of Religions..., 54.

${ }^{40}$ The opinion of Gerber, as stated in Ihsan Yilmaz, Muslim Laws, Politics and Society in Modern Nation States: Dynamic Legal Pluralisms in England, Turkey and Pakistan, Burlington, VT: Ashgate, 2005.
} 
Javanese culture is flexible. Java conception of religiosity connected on the intellectual and spiritual tradition of Islam, as a process that is sometimes regarded as indigenization. ${ }^{41}$ Islam has a mystical-spiritual dimension that is equal to the Javanese philosophy, which sees human existence can not be separated from the cosmological context, which makes life itself as a religious experience and mystical journey. ${ }^{42}$

Historical and religious experience of the Javanese community suggested that all of external ideologies and practices would be filtered to be adjusted with the culture and views of Javanese, including Hindu and Buddhism. A study by Vickers took the evidence of the people of Bali that their contemporary culture are considered as the heritage of Hindu Majapahit that fled to Bali due to the Islamization of Java. ${ }^{43}$ The vigorous and pervasive Islamization to Java at the end of the 14th century until the beginning of the 16th century were not entirely filled with peace. Evacuation of Hindu followers was related to the collapse of the Hindu based Javanese kingdom of Majapahit and the establishment of an Islamic sultanate of Demak. ${ }^{44}$ As a result of the pressure and the propagation, the Hindu followers, aristocrats and peasants who reject Islam fled to Bali and contributed to the formation of religious and cultural heritage of Majapahit-style Balinese tradition. Another Hindu group who remained in Java fled to remote areas like Tengger in Mount Bromo which has some tradition similarities with popular ritual of Balinese. ${ }^{45}$

${ }^{41}$ Clifford Geertz," Popular Art" and the Javanese Tradition”, Indonesia, Volume 50 (1990), 77-94.

${ }^{42}$ Astri Wright, "Javanese Mysticism and Art: A Case of Iconography and Healing", Indonesia, Volume 52 (1991), 87.

43 Adrian Vickers, "Hinduism and Islam in Indonesia: Bali and the Pasisir world", Indonesia, Volume 44 (1987), 31-58.

${ }^{44}$ Slamet Muljana, Runtuhnya Kerajaan Hindu-Jawa dan Timbulnya Negara-negara Islam di Nusantara, Yogyakarta: PT LKiS Pelangi Aksara, 2005, 175-193.

45 Robert W Hefner, Hindu Javanese: Tengger Tradition and Islam, Princeton University Press, 1990. 
The thesis of Picard and Madinier revealed that the Balinese Hindu did not origin from India, but from Majapahit. Balinese tradition reflects Hinduism local native, which experiences the acculturation adapted to the local context, as a living museum for the ideas of Majapahit, similar to Javanese Muslims as a living museum for Islamic-oriented Javanese culture. ${ }^{46}$ The establishment of cultural amalgalm is the result of intense interaction between the two entities, which Islam as a new entity inherited many relics in the form of ideas, systems and artifacts of HinduBuddhist that formerly master Java for centuries.

There are at least four identity relations of Islam and Javanese culture in the knowledge and practical dimension, the genealogy of culture, the mystical dimension of Islam, and the conception of the power of Javanese. First, the relationship between Islam and Hinduism and Buddhism may be identified as a double genealogy of culture, as Islam inherited the influence of Hindu Buddhist culture toward Javanese people. This double genealogy formed the political, spiritual and cultural dimension of Javanese people. In the Javanese literature, for example, Serat Sajarah Leluhur, mentioned many figures of prophets originating from Muslim bibliography as well as the puppet characters from the Hindu cosmological entities which used as a source of spiritual and political authority of kings power of Javanese Islam. ${ }^{47}$ Although the literature was written by Muslims, Hindu terminology could not be avoided since it represents Hindu as a lingua franca in the early Islamization of Java. ${ }^{48}$ The double

\footnotetext{
${ }^{46}$ Michel Picard and Rémy Madinier (ed.), The politics of Religion in Indonesia: Syncretism, Orthodoxy, and Religious Contention in Java and Bali, London: Routledge, 2011, 118-122

${ }^{47}$ R Kevin Jaques, "Sajarah Leluhur: Hindu Cosmology and the Construction of Javanese Muslim Genealogical Authority”, Journal of Islamic Studies Volume 17, Number 2 (2006), 129.

48 This book uses names like Adam to justify divine knowledge possessed by Javanese kings, then continues on Adam grandson named Anwar. It also uses figures from Hindu traditions as the use of Puranas and Mahabharata, the figures adopted from Javanese puppet characters. See R Kevin Jaques, "Sajarah Leluhur: Hindu Cosmology..., 129.
} 
genealogy was also used as a justification mythology in the form of literature, and kasekten ritual or martial prowess by Javanese Muslims. ${ }^{49}$ For example, the concept of woman magical spirit, Nyi Roro Kidul, derived from the figure of the Hindu pre-Majapahit, Ken Dedes, who is considered as a source of magical-supernatural power for Javanese. ${ }^{50}$ Many rituals held in her honor, especially on the south coast, and used as a source of political and spiritual authority of the Mataram sultanate power.

Second, aspects of mysticism. Mysticism is the actualization of Islam by Kejawen groups that give more emphasis on the mystical dimension rather than legalistic and ritualistic Islam. ${ }^{51}$ The magical and mystical powers are dominant elements for Javanese people. Mysticism is the main shaper element of spiritual locus of magico-spiritual oriented Javanese community compared with scripture elements in accepting the teachings of Islam. Woodward pointed out that the Javanese traditional medicine based on ideas, knowledge and magical powers in Islamic Sufism. This world view encourages the two forms of modalities of medical practices that are contrary, one based on the shaman of magical specialist (dukun), while another religiously validated by sufi saints. ${ }^{52}$

Mysticism, as the search for the inner self, is the core concept of peace of mind, soul connection with the cosmos, and union with God. ${ }^{53}$ Esoteric element is very strong in the tradition spiritual orientation of Kejawen, in line with the values of Islamic mysticism or sufism. There-

\footnotetext{
${ }^{49}$ Martin van Bruinessen, "Global and Local in Indonesian Islam", Southeast Asian Studies, Volume 37, Number 2 (2007), 52.

${ }^{50}$ Bianca J Smith and Mark Woodward, "Magico-spiritual Power, Female Sexuality and Ritual Sex in Muslim Java: Unveiling the Kesekten of Magical Women”, The Australian Journal of Anthropology, (2015).

${ }^{51}$ Robert W Hefner, "Islam, state, and civil society..., 1-35 ; JA Niels Mulder, "Abangan Javanese religious thought and practice..., 260-267.

${ }^{52}$ Martin van Bruinessen, "Global and local in Indonesian Islam..., 46-63.

${ }^{53}$ Khoon Choy Lee, A Fragile Nation: The Indonesian Crisis, Singapore: World Scientific, 1999, 108; JA. Niels Mulder, “Abangan Javanese religious thought and practice..., 260-267.
} 
fore, the aspect of Sufism is more accepted by the elite and the common people in early Islam because it is consistent with previous behavior appllied to the teaching of mystical orientation of Hinduism and Buddhism. Therefore, there are a lot of traditions, celebrations and customs of Javanese such as tapa, slametan, naloni, mitoni, patangpuluhan, nyatus, nyewu that have deep roots in the beliefs of kebatinan.

Third, the teaching of boarding schools (pondok pesantren). Pesantren becomes an institution with an excellent combination elements of religious teaching, liturgy, worship practices and mystical Islam and Javanese tradition. ${ }^{54}$ The Javanese believe that clerics are the holder of key to divine mysteries. ${ }^{55}$ Historically, Islamic pesantrens are the successor of such boarding developed by Hindu and Buddhist tradition. Islamic boarding schools in Java teach the practice of sufism which essentially oriented and implemented on mystical behavior that also lived among Kejawen. ${ }^{56}$ The clerics also roles as the guardian of traditional ideology of Javanese Islam. ${ }^{57}$ The traditional curriculum of Islamic education institutions from three centuries ago, more emphasis on the social conditions of society, and less attention toward formality aspects of Islamic teaching. ${ }^{58}$

Fourth, the Javanese community conceptions of power. The political and religious system give us an overview of structural uniformity of cultural domains which is derived from a hierarchical organization such as knowledge of the culture with the medical aspects which are inseparable

\footnotetext{
${ }^{54}$ James Fox, Currents in contemporary Islam in Indonesia, Paper originally presented at Harvard Asia Vision Cambridge, Massachussetts, (29 April-1 May, 2004), 3.

${ }^{55}$ Sidney Jones, "Arabic Instruction and Literacy in Javanese Muslim Schools", International Journal of the Sociology of Language, Volume 42 (1983), 83-94.

${ }^{56}$ James Fox, Currents in contemporary Islam in Indonesia..., 3.

${ }^{57}$ Zamakhsyari Dhofier, "The Pesantren Tradition: A Study of the Role of the Kyai in the Maintenance of the Traditional Ideology of Islam in Java..., (2014).

${ }^{58}$ Khoon Choy Lee. A fragile nation..., 108.
} 
from the world view of Javanese..$^{59}$ In the concept of power, Hinduism and Buddhism tradition genealogy to Islam has implications for Javanese to unify the conception of spiritual authority and political absolutum dominium on one authority, by making the sultan as a representation of divine power, the ruler of the world and religion as well as recipients of God's mystical knowledge. ${ }^{60}$

\section{Conclusion}

The components of Islamic culture as the origin of discourse relating universal and local actualization. The Muslims universally recognizes the need for interaction with the Quran and Hadith, ritual and liturgy, congregation prayer, social services such as zakat, and pilgrimage as the Hajj, as well as abstinence like fasting. However, these universal values might be specified by the local context and did not implemented completely. ${ }^{61}$ This contextualization arises from the interaction between the local culture and acceptance of Islam.

The principle of assimilation of Islam and local actualization, not only occured in the social aspect, but also liturgical dimension. For instance, Friday sermon functioned as the interactions between textual and local traditions, in which the preacher had a chance to articulate a formal religious message of Islam to the needs and problems of communities, accordance with their world view and education level of community. ${ }^{62}$ In addition, the non hajj pilgrimage symbolically seen as an expression of regional culture of Islam, especially in non-Arab countries. However, the view which only focuses on the dimensions of ritualistic pilgrimage as a

\footnotetext{
${ }^{59}$ Mark R. Woodward, "Healing and Morality: a Javanese Example”, Social Science $\mathfrak{E}$ Medicine, Volume 21, Number 9 (1985), 1007-1021.

${ }^{60}$ R. Kevin Jaques, "Sajarah Leluhur: Hindu Cosmology and ..., 129-157.

${ }^{61}$ Woodward as quoted by Ronald Lukens-Bull. "Between text and practice..., 60.

${ }^{62}$ Ronald Lukens-Bull, "Between text and practice..., 60.
} 
universal ritual of Islam can reduce the focus on non Hajj pilgrimage at various sanctuaries and shrines as the actualization of Islam in the local context. ${ }^{63}$

Dissemination of knowledge of Sufism in Java raised Javanese mysticism as a unique fascia of Javanese culture containing animism, dynamism, Hinduism and Buddhism and Islam. Most of the people who practice the Javanese beliefs and practices identify themselves as Muslims. The existence of Javanese Islam has been maintaining relevant and unique shades of Indonesian Islam, and enriching cultural actualization of Islam as universal religion. Thus, it would seem artificial to distinguish between Islam on the one hand with kejawen on the other. Hence, kejawen properly described as Javanese Sufism rooted in Islam.

The study concluded that Geertz's typology of abangan and santri only relevant in terms of the social beings. Islam and Javanese culture syncretism did not occur in the aspects of worship and faith. This study revealed Islam as a religious as well as discursive tradition has diverse actualization within its local context. Thus, Javanese culture and its accompanying rituals of Islam can not necessarily be referenced as a syncretic or deviation. Historical evidence of Islamization in Indonesia showed that the nuances of Islamic locality can be tracked since early process. Its arrival in Indonesia met the social conditions that already have values, knowledge and traditional beliefs that have been established and embraced a long time since pre-Islamic era. The development of Islam in Indonesia is a result of peaceful propaganda characterized as acculturative and adaptive that were easily accepted by the local community. ${ }^{64}$

${ }^{63}$ Surinder Bhardwaj, "Non-hajj Pilgrimage in Islam: A Neglected Dimension of Religious Circulation", Journal of Cultural Geography, Volume 17, Number 2 (1998): 69-87; Martin van Bruinessen, "Global and Local in Indonesian Islam..., 46-63.

${ }^{64}$ Malise Ruthven and Nanji Azim, Historical Atlas of Islam, Cambridge (Massachusetts): Harvard University Press, 2004, 106; Richard Z. Leirissa, "Dr. J.C Van Leur dan Sejarah 


\section{Acknowledgement}

This article adapted form theoretical perspective of the authors' book, 'The Role of Industrialization in the Change of Islamic Identity of Indigenous Samin in the Mountains Region of North Kendeng (A Study of Sociology of Da'wah)', published by the Institute for Research and Community Service (LP2M) State Islamic University of Walisongo in 2014. The authors would like to announce our sincere thank to Mudjahirin Thohir, from Faculty of Cultural Studies of Diponegoro University for his valuable comments and suggestions of revised draft of the article. The author also thank to M Mukhsin Jamil, from UIN Walisongo Semarang for his constructive supervision during the field study. The author would like to thank to the staff of LP2M IAIN of Walisongo for the financial support provided for this research through Competitive Research Program for Faculty and Students in 2014. Any errors, of course, are our own responsibility.

\section{Bibliography}

Ashforth, Blake E., and Fred Mael, "Social identity theory and the organization", Academy of management review, Volume 14, Number 1 (1989): 20-39.

Barrett, J. L., "Exploring the natural foundations of religion", Trends in Cognitive Sciences, Volume 4 Number 1 (2000): 29-34.

Beatty, Andrew, "Adam and Eve and Vishnu: Syncretism in the Javanese slametan”, Journal of the Royal Anthropological Institute, (1996): 271-288.

Bhardwaj, Surinder. "Non-hajj pilgrimage in Islam: A neglected dimension of religious circulation." Journal of Cultural Geography, Volume 17, Number 2 (1998): 69-87;

Ekonomi: Suatu Tinjauan Histografi” in Sejarah Indonesia: Penilaian Kembali Karya Utama Sejarawan Asing, Depok: Pusat Penelitian Kemasyarakatan dan Budaya Lembaga Penelitian University of Indonesia, 1997, 193; Abdurrahman Kasdi, "Pendidikan Multikultural Di Pesantren: Membangun Kesadaran Keberagamaan yang Inklusif”, Jurnal Ad-Din STAIN Kudus, Volume 4, Number 2 (2012), 218. 
Brakel, Lode Frank, "Islam and local traditions: syncretic ideas and practices", Indonesia and the Malay world, Volume 32, Number 92 (2004): 5-20.

Dhofier, Zamakhsyari, "The Pesantren Tradition: A Study of the Role of the Kyai in the Maintenance of the Traditional Ideology of Islam in Java", Ph.D. Theses, Australia National University, 1980.

Eickelman, Dale, "The study of Islam in local contexts", in Contributions to Asian Studies, 17 (1982).

Esposito, John L. Oxford History of Islam. New York : Oxford University Press, 1999.

Fox, James, "Currents in contemporary Islam in Indonesia", paper originally presented at Harvard Asia Vision 2129 April - 1 May, 2004 Cambridge, Massachussetts.

Geertz, Clifford, "Popular Art and the Javanese Tradition", Indonesia and the Malay World, Volume 50 (1990): 77-94.

Geertz, Clifford. Religion as a cultural system. In: The interpretation of cultures: selected essays. Fontana Press, 1993.

Geertz, Clifford. Religion of Java. Chicago: The University of Chicago Press, 1960.

Geertz, Clifford. The interpretation of cultures: Selected essays. Volume 5019. Basic books, 1973.

Hawkins, Mary, "Is Rukun dead? Ethnographic interpretations of social change and Javanese culture", The Australian journal of anthropology, Volume 7, Number 1 (1996): 218-234.

Heady, Amber, and Lynn Ruffner, "Religion and sociological perspective", Religion, Volume 8 (2010): 31.

Hefner, Robert. W. Hindu Javanese: Tengger Tradition and Islam. Princeton: Princeton University Press. 1990.

Hefner, Robert. W., "Islam, state, and civil society: ICMI and the struggle for the Indonesian middle class", Indonesia and the Malay World, Volume 56 (1993): 1-35.

Hefner, Robert. W., "Islamizing Java? Religion and Politics in Rural East Java", The Journal of Asian Studies, Volume 46, Number 03 (1987): 533-554.

Hooker, M. B., "Muhammadan Law and Islamic Law", in Hooker (ed.), Islam in South-East Asia. Leiden: E.J. Brill, 1988.

Jaques, R. Kevin, "Sajarah Leluhur: Hindu Cosmology and the Construction of Javanese Muslim Genealogical Authority”, Journal of Islamic Studies, Volume 17, Number 2 (2006): 129-157. 
Jones, Sidney, "Arabic instruction and literacy in Javanese Muslim schools", International Journal of the Sociology of Language, Volume 42 (1983): 83-94.

Kasdi, Abdurrahman, "Pendidikan Multikultural di Pesantren: Membangun Kesadaran Keberagamaan yang Inklusif", Jurnal Ad-Din STAIN Kudus, Volume 4, Number 2 (2012): 218.

Lee, Khoon Choy. A Fragile Nation: The Indonesian Crisis. World Scientific, 1999.

Leirissa, Richard Z. "Dr. J.C Van Leur dan Sejarah Ekonomi: Suatu Tinjauan Histografi" dalam Sejarah Indonesia: Penilaian Kembali Karya Utama Sejarawan Asing. Depok : Pusat Penelitian Kemasyarakatan dan Budaya Lembaga Penelitian Univ. Indonesia. 1997.

Lukens-Bull, Ronald, "Between text and practice: Considerations in the anthropological study of Islam”, Defining Islam: A Reader Volume 59 (2016): 60.

Madjid, Nurcholis, "Islamic Roots of Modern Pluralism: Indonesian Experience." Studia Islamika, Volume 1, Number 1, (1994): 55-77.

Moore, Jerry D. Visions of culture: an introduction to anthropological theories and theorists. Rowman Altamira, 2000.

Mulder, JA. Niels, "Aliran Kebatinan as an Expression of the Javanese worldview", Journal of Southeast Asian Studies, Volume 1, Number 2 (1970): 105.

Mulder, JA. Niels, "Abangan Javanese religious thought and practice”, Bijdragen tot de Taal, Land-en Volkenkunde 2/3de Afl (1983): 260-267.

Muljana, Slamet. Runtuhnya kerajaan Hindu-Jawa dan timbulnya negara-negara Islam di Nusantara. Yogyakarta: PT LKiS Pelangi Aksara, 2005.

Nasution, Harun dkk (ed). Ensiklopedia Islam Indonesia. Jakarta : Djambatan. 1992

Picard, Michel, and Rémy Madinier (eds.). The politics of Religion in Indonesia: Syncretism, orthodoxy, and religious contention in Java and Bali. London: Routledge, 2011.

Ricklefs, Merle Calvin, "The birth of the abangan”, Bijdragen tot de taal-, land-en volkenkunde/Journal of the Humanities and Social Sciences of Southeast Asia, Volume 162, Number 1, (2006): 35.

Ricklefs, Merle Calvin. Islamisation and Its Opponents in Java. Singapore: NUS Press. 2012

Ricklefs, Merle Calvin. Mystic synthesis in Java: a history of Islamization from the fourteenth to the early nineteenth centuries. EastBridge, 2006

Roberts, Keith A., and David Yamane. Religion in sociological perspective. London: Sage Publications, 2014. 
Ruthven, Malise and Nanji Azim. Historical Atlas of Islam. Cambridge (Massachusetts): Harvard University Press. 2004.

Smith, Bianca J., and Mark Woodward, "Magico spiritual power, female sexuality and ritual sex in Muslim Java: Unveiling the kesekten of magical women", The Australian Journal of Anthropology (2015).

Swidler, Ann, "Culture in action: Symbols and strategies", American sociological review (1986): 273-286.

van Bruinessen, Martin. M., "Global and local in Indonesian Islam", Southeast Asian Studies, Volume 37, Number 2 (2007): 46-63.

Vatikiotis, Michael RJ. Political change in Southeast Asia: Trimming the banyan tree. Volume 10. London: Taylor \& Francis, 1996.

Vickers, Adrian, "Hinduism and Islam in Indonesia: Bali and the Pasisir world", Indonesia, Volume 44 (1987): 31-58.

Woodward, Mark R., "Healing and morality: a Javanese example", Social Science $\mathcal{E}$ Medicine Volume 21, Number 9 (1985): 1007-1021.

Woodward, Mark R. Islam in Java: Normative Piety and Mysticism in the Sultanate of Yogyakarta. Association for Asian Studies Monograph XLV Tucson: The University of Arizona Press, 1989.

Woodward, Mark R., "The Slametan": Textual Knowledge and Ritual Performance in Central Javanese Islam", History of Religions (1988): 54-89.

Wright, Astri, "Javanese Mysticism and Art: A Case of Iconography and Healing", Indonesia and the Malay World, Volume 52 (1991): 85-104.

Yilmaz, Ihsan. Muslim laws, politics and society in modern nation states: Dynamic legal pluralisms in England, Turkey and Pakistan. Burlington, VT: Ashgate, 2005.

Yinger, J. Milton. Religion, society and the individual; an introduction to the sociology of religion. Oxford, England: Macmillan. 1957.

Further Readings:

Errington, J. Joseph, "Self and self conduct among the Javanese priyayi elite", American Ethnologist Volume 11, Number 2 (1984): 275-290.

Roff, William. R., "Islam Obscured? Some reflections on studies of Islam \& society in Southeast Asia”, Archipel, Volume 29, number 1 (1985): 7-34.

Rutherford, Danilyn, et al., "After syncretism: The anthropology of Islam and Christianity in southeast Asia: A review article" (2002): 196-205. 